\title{
Knowledge of HIVIAIDS and Risk Behaviour among Students of Colleges of Education in Edo State, Nigeria
}

\author{
Olubayo-Fatiregun Martina Abebi \\ Department of Physical and Health Education, Faculty of Education \\ Obafemi Awolowo University, Ile-lfe, Osun State, Nigeria. \\ Email: martolufat@yahoo.co.uk
}

\section{Doi:10.5901/jesr.2014.v4n6p251}

\begin{abstract}
This study examined the knowledge and risk behaviours on HIVIAIDS of students in colleges of Education in Edo State. The study sampled 1600 students (male and female) from two colleges of Education. A descriptive survey was adopted for the study using stratified random sampling techniques. A self- developed questionnaire served as data collection tool. The data analysis was done using descriptive statistics of frequencies and percentages, while t-test and multiple regression analyses were used to test the hypothesis at 0.05 level of significance. Result showed that many of the students both males and females in these colleges still do not have enough knowledge about HIVIAIDS. Misinformation about HIVIAIDS prevention still persists and pronounced among the students despite all the efforts of the national and international organizations. There is need for HIVIAIDS education in all Colleges of Education and other tertiary institutions in Nigeria to be taken more seriously. Despite the high level of knowledge of some of the students, their risky-behaviour has not changed as expected.
\end{abstract}

Keywords: Risk-behaviour, knowledge, HIVIAIDS College of Education Ekidialor and Igueben

\section{Introduction}

The Human Immune Deficiency Virus (HIV) IAcquired Immune Deficiency Syndrome (AIDS) has become the most devastating disease mankind has ever faced. UNAIDS (2001).The HIVIAIDS has set off a pandemic with the worst hit region being sub-Sahara Africa. (UNAIDS, 1999). As at the end of 2001, of the estimated 40 million adults and children living with HIVIAIDS, 28.1 million were in sub-Sahara Africa with an adult prevalence rate of $8.4 \%$. In Nigeria the most populous country in sub-Africa, the prevalence as at 2001 was put at $5 \%$ which represented a significant population of people living with HIVIAIDS. (UNAIDS, 2001), The rate of infection has continued to increase since 1986 when first case of AIDS was discovered. The sentinel survey reported also that the increase rate cut across male and female age 15-49. This translates into over 2.8 million people living with HIVIAIDS as at then. (UNESCO, 2003). It is evident that in some countries including Nigeria efforts are being made to deal with the disease HIVIAIDS. The Millennium Developmental Goal of the former president Olusegun Obasanjo 2003 was very emphatic on eradication of HIVIAIDS in Nigeria. In spite of desperate out cry of the government, NGOS, and individual organizational efforts so far, the responses to the epidemic is limited and the coverage of the core activities of HIVIAIDS remains critically low.

The report of the 2005 sero prevalence sentinel survey in Nigeria indicates that the prevalence of HIVIAIDS was $4.4 \%$. This shows some sign of improvement to the earlier report of $5 \%$ as reported UNAIDS 2001 due to several intervention strategies of the government and individual. Federal Ministry of Health FMH (2005) reported that traditional belief, cultural factors, lack of knowledge about the disease and poverty were the most important factors highlighted for the increasing HIVIAIDS prevalence in Nigeria. Moreover, unprotected sex with several partners having extra marital relationship especially among young boys and girls and early marriage are the various risks factors for HIV infections.

The U.S department of state (2008) also reported that in Nigeria, the HIV prevalence rate among adults age 15-49 is $3.9 \%$. Nigeria has the third largest number of people living with HIV. The HIV epidemic in Nigeria is complex and varies widely by region. In some States, the epidemic is more concentrated and driven by high risk behaviours, while other State have more generalized epidemics that are sustained primarily by multiple sexual partnerships in the general population. Youth and young adults in Nigeria are particularly vulnerable to HIV, with young women at higher risk than young men. According to U.S. Department (2008) reports, there are many risk factor that contribute to the spread of HIV, including lack of adequate knowledge, prostitution, high risk practices among students and itinerant workers, high prevalence of sexually transmitted infections, clandestine high risk heterosexual and homosexual practices, international 
trafficking of women and young girls and irregular blood screening. Around the world there is also an increasing concern about young people's knowledge and risk behaviour of early and unprotected sexual relation. The AIDS epidemic has made it necessary to teach young people effective sexual health and AIDS preventive programs that can increase and maintain desirable behaviour that can virtually eliminate their risk of becoming infected. Nkya, Gillespie, Howlet, (1991) stated that it has been recognized for many years that population with high number of sexual contacts, high HIV and STI prevalence and low condom use play key role in the transmission of HIV.

Muyiwa (1989), stated that in college of Education where we have a creme of youths, sexual behaviour and adventures poses serious moral and health problems. Muyiwa (1989) also opined that, in schools, on the streets and boardrooms, sex is sold and bought for as little as a price of lunch, posing serious, moral and health problems for Nigerians. In Nigerian schools and institutions of high learning, students who are supposed to study and become leaders of tomorrow are combining their studies with the world's oldest profession-prostitution. This they tagged campus "prostitution or sex escapes, junk trade and sex racket". This sexual problem is not limited to only universities, tagged tertiary institutions but is applicable and practiced in all schools; polytechnics, colleges of education and secondary schools. However students of colleges of Education in Nigeria tend to engage in high-risk sexual behaviour that is known to increase the prevalence of HIVIAIDS. Gesto (2004), stated that tertiary institutions are regarded as the cohort zones for HIVIAIDS. This is because the students are young and sexually active, with many of them having more than one sexual partners. Gesto (2004) also advanced that some factors responsible for this behaviour could be ascribe to poor economic status which forces some of the female students to engage in commercial sex to pay for their education and the expensive life while in school.

The Federal Government has adopted so many measures ranging from public enlightenment, campaign radio and television jingles to newspaper advertisement to stem the tide of AIDS in the country at large. The war has been carried to educational institutions through workshops and seminars and many testing centers for AIDS detection have been established which carters for individuals without any fees charged. Both nationals and international organization have been put in place to sensitized people on the ills of HIV and the need to change our risky sexual behaviours. Inspite of all these efforts, the epidemic still presents serious challenges. Every year increasing numbers of young people between ages 15-40 years are infected with HIV globally. The reason for this is not far fetch. The young people nowadays are more sexually active than those of the previous generation. Therefore there is need to provide adequate information on the knowledge of HIVIAIDS to these teaming populations to enhance their awareness and perception on the dreaded disease. AIDS Education for these young people is a crucial weapon in HIV knowledge and preventive measurement.

\section{Purpose of Study}

The study aimed at finding out the knowledge and risk behaviour on HIVIAIDS among the students of colleges of education in Edo State with the intention to update their knowledge and provide useful information in planning effective HIVIAIDS programmes that would help in shaping some of the risky-taking behaviour prevalent among students.

The specific objectives of this study are to:

a. determine the knowledge of the students about HIVIAIDS

b. identify the involvement of the students in HIVIAIDS risk behaviours

c. assess the influence of the student's knowledge of HIVIAIDS on their involvement in risk-taking behaviour

d. find out measure of achieving positive behavioural changes towards HIVIAIDS risk taking behaviours.

\section{Hypotheses}

The following hypotheses were generated:

1. There will be no significant difference between HIVIAIDS knowledge of students from the two Colleges of Education.

2. There will be no significant difference between HIVIAIDS risk-taking behaviours of the students of the two Colleges of education

3. HIVIAIDS knowledge will not significantly influence the students involvement in HIVIAIDS risk-taking behavours 


\section{Methodology}

Descriptive survey research design is used for the study. The study population is made up 1600 male and female students studying in the two colleges of education (Ekidialor and Igueben in Edo State using stratified random sampling techniques.

The research instrument for the study is a self constructed questionnaire items, validated by experts in the field of health education. The reliability coefficient was put at 0.86 , using cronbach alpha. The questionnaire was administered to the 1600 students using four research assistants, two in each college. Data analysis involves the use of descriptive statistics of frequencies and percentages and inferential statistics of t-test and regression analysis at 0.05 level of significance.

\section{Results}

The results for this study are presented in Tables I-X

Table I: Percentage Distribution of Age Range of Respondents N = 1600

\begin{tabular}{|l|c|c|}
\hline Age Range & Frequency & Percentage (\%) \\
\hline 14 to 25 years & 1256 & 78.5 \\
\hline 26 to 50 years & 344 & 21.5 \\
\hline Above & - & - \\
\hline Total & 1600 & 100.0 \\
\hline
\end{tabular}

Table I above shows the age range of the students. Ages $14-25$ years present the highest population with $1256(78.5 \%)$ followed by $26-50$ years with $344(21.5 \%)$.

Table II: Percent distribution of respondent by sex $\mathrm{N}=1600$

\begin{tabular}{|l|c|c|}
\hline Gender & Frequency & $(\%)$ \\
\hline Male & 800 & 50.0 \\
\hline Female & 800 & 50.0 \\
\hline Total & 1600 & 100.0 \\
\hline
\end{tabular}

Table II above shows equal representation of the respondents for the study with 800 females $(50,0 \%)$ and 800 males $(50.0 \%)$

Table III: Percentages distribution of Respondents Knowledge on existence on HIVIAIDS N = 1600

\begin{tabular}{|l|c|c|}
\hline Variable & Frequency & Percentage (\%) \\
\hline Strongly Disagreed & 793 & 49.6 \\
\hline Disagreed & 437 & 27.3 \\
\hline Agreed & 204 & 12.8 \\
\hline Strongly Agreed & 166 & 10.4 \\
\hline
\end{tabular}

Table III reveals the students responses to the existence of HIVIAIDS. Out of the 1600 students, 793 representing $49.6 \%$ strongly disagreed to the statement that AIDS does not exist", 437(27.3\%) disagreed. While 204(12.8\%) and $1166(10.4 \%)$ respectively agreed and strongly agreed that AIDS does not exist. 
Table IV: Percentage distribution of Respondents on unprotected sexual intercourse with positive persons

\begin{tabular}{|l|c|c|}
\hline Variable & Frequency & Percentage (\%) \\
\hline Strongly Disagreed & 114 & 7.1 \\
\hline Disagreed & 119 & 7.4 \\
\hline Agreed & 599 & 37.4 \\
\hline Strongly Agreed & 768 & 48.0 \\
\hline Total & 1600 & 100.0 \\
\hline
\end{tabular}

Table IV presents respondent's view on unprotected sex with an infected person. It revealed that 114 (7.1\%) and 119(7.4\%) respectively disagreed that having unprotected sex with an infected person causes HIVIAIDS while 768(48.0\%) and 599(37.4\%) vehemently agreed and strongly agreed that unprotected sex with an infected victim facilitate the transmission of HIVIAIDS.

Table V: Percentage distribution of respondents on having sexual intercourse at any available opportunity

\begin{tabular}{|c|c|c|}
\hline Respondents & Frequency & Percentage (\%) \\
\hline No & 1412 & 88.3 \\
\hline Yes & 188 & 11.8 \\
\hline Total & 1600 & 100.0 \\
\hline
\end{tabular}

Table $V$ above shown respondents responses on HIVIAIDS risky behaviour 1412 respondents representing $88.3 \%$ of the total population had never had sex at any available opportunity, while 188(11.8\%) had had sex at any given opportunity.

Table Vl: Responses on having multiple sexual partners

\begin{tabular}{|c|c|c|}
\hline Respondents & Frequency & Percentage (\%) \\
\hline No & 1247 & 77.9 \\
\hline Yes & 353 & 22.1 \\
\hline Total & 1600 & 100.0 \\
\hline
\end{tabular}

Table VI above shown having multiple sexual partner reveals that, 1247(77.9\%) disassociate themselves from such risky-behaviour while 352(22.1\%) agreed having more than one sexual partners.

\subsection{Hypothesis One}

The hypothesis stated that there will be no significant differences between HIVIAIDS from the two Colleges of Education.

Table VII: Shows the t-test table of the respondents differences in HIVIAIDS knowledge of two colleges of Education (Ekidialor and Igueben)

\begin{tabular}{|l|c|c|c|c|c|c|}
\hline \multicolumn{1}{|c|}{ Variable } & Group & $\mathbf{F}$ & Sig & $\mathbf{t}$ & df & Sig(2- tailed) \\
\hline AIDS does not exist & $\begin{array}{c}\text { Equal variance assumed (EVA) } \\
\text { Equal variance not assumed }\end{array}$ & .000 & .989 & $\begin{array}{l}2.036 \\
2.036\end{array}$ & 15 & $\begin{array}{l}0.42 \\
0.42\end{array}$ \\
\hline Virus & $\begin{array}{c}\text { EVA } \\
\text { EVNA }\end{array}$ & .110 & .740 & -5.351 & 15 & $\begin{array}{l}.000 \\
.000\end{array}$ \\
\hline Causal factors of AIDS: 'A' & $\begin{array}{c}\text { EVA } \\
\text { EVNA }\end{array}$ & .045 & .833 & -655 & 15 & .513 \\
\hline Signs \& symptoms of AIDS: 'B' & $\begin{array}{c}\text { EVA } \\
\text { EVNA }\end{array}$ & .003 & .956 & $\begin{array}{l}-844 \\
-844\end{array}$ & 15 & $\begin{array}{l}.399 \\
.399\end{array}$ \\
\hline Assonated problems of AIDS. 'B' & $\begin{array}{c}\text { EVA } \\
\text { EVNA }\end{array}$ & .003 & .956 & $\begin{array}{l}-844 \\
-844\end{array}$ & 15 & $\begin{array}{l}.399 \\
.399\end{array}$ \\
\hline Prevention/treatment of AIDS: 'A' & $\begin{array}{c}\text { EVA } \\
\text { EVNA }\end{array}$ & 5.365 & .021 & -7.684 & 15 & .000 \\
\hline
\end{tabular}


Table VII above shows that the t-value of $2.036,-5.351,8.398,-844$ and -7684 were found. The t-test analysis revealed in table vi that HIVIAIDS knowledge of the students of the two colleges was statistically not significant (f(df $=15, p>.05)=$ 2.036). The hypothesis was therefore accepted.

\subsection{Hypothesis Two}

The hypothesis stated that there will be no significant differences between HIVIAIDS risk-taking behaviours of the students of the two College of Education.

Table VIII: t-test Analysis of the difference between HIVIAIDS risk-taking behaviours the two colleges of Education

\begin{tabular}{|l|c|c|c|c|c|c|}
\hline \multicolumn{1}{|c|}{ Variable } & Group & F & Sig & t & Df & Sig (2- tailed) \\
\hline AIDS sex at any available time & $\begin{array}{c}\text { Equal Volume assumed (EVA) } \\
\text { Equal Variance not Assumed (EVNA) }\end{array}$ & 6.190 & .013 & $\begin{array}{l}1.242 \\
1.242\end{array}$ & 15 & .214 \\
.214 \\
\hline $\begin{array}{l}\text { I often use condom during } \\
\text { sexual intercourse }\end{array}$ & $\begin{array}{c}\text { EVA } \\
\text { EVNA }\end{array}$ & 19.521 & .000 & $\begin{array}{l}2.471 \\
2.471\end{array}$ & 15 & .014 \\
\hline I have multiple sexual partners & $\begin{array}{c}\text { EVA } \\
\text { EVNA }\end{array}$ & 14.041 & .000 & $\begin{array}{l}-1.870 \\
-1.870\end{array}$ & 15 & .062 \\
\hline $\begin{array}{l}\text { I use one condom twice for } \\
\text { intercourse }\end{array}$ & $\begin{array}{c}\text { EVA } \\
\text { EVNA }\end{array}$ & .323 & .569 & .285 & 15 & .285 \\
\hline I am afraid of HIVIAIDS testing & EVA & .651 & .420 & $\begin{array}{l}-5.962 \\
-5.962\end{array}$ & 15 & .776 \\
\hline I share instruments with friends & $\begin{array}{c}\text { EVA } \\
\text { EVNA }\end{array}$ & 9.793 & .002 & $\begin{array}{l}-1.561 \\
-1.561\end{array}$ & 15 & .000 \\
\hline
\end{tabular}

Table VIII above shows the t-test value of the six variables above $1.242,2.471,-1.870, .285,-5.962$, and -1.561 . The ttest result revealed that HIVIAIDS risky behaviour of the students of the two colleges was not statistically significant ( $f$ (df $=15, p>05)=1.242$. The null hypothesis was accepted.

a. Predictors: (constant), prevention/Treatment of AIDS: G, causal factors of AIDS: A, AID does not exist. Prevention/treatment of AIDS: F, Prevention/treatment of AIDS: B

\subsection{Hypothesis Three}

The hypothesis states that HIVIAIDS knowledge will not significantly influence the student's involvement in HIVIAIDS risk-taking behaviours.

Table IX: Influence of HIVIAIDS knowledge of students as shown in table of model summary A \& B

Model Summary ' $A$ '

\begin{tabular}{|c|c|c|c|c|}
\hline Model & $\mathrm{R}$ & $\mathrm{R}$ square & Adjusted R square & Stand. Error of the Estimate \\
\hline 1 & .054 & .003 & .000 & .688 \\
\hline
\end{tabular}

Model Summary "B"

\begin{tabular}{|c|c|c|c|c|c|c|}
\hline S/N & Model & Sum of Squares & df & Mean Square & f & \\
\hline \multirow{2}{*}{1} & \multirow{2}{*}{ Regression residual Total } & 2.224 & 5 & .445 & & \\
& & 753.816 & 1594 & & .941 & .4549 \\
& & 756.040 & 1599 & .473 & & \\
\hline
\end{tabular}

The multiple regression analysis of hypothesis III is shown on table IX Model Summary A \& B revealed that the knowledge of HIVIAIDS do not significantly influence the college students involvements in HIVIAIDS risk-taking behaviour was statistically significant $(f(d f=5, p>.05)=941)$. Hypothesis was therefore rejected. It therefore means that HIVIAIDS knowledge will influence students' involvement in HIVIAIDS risky-behaviour.

a. Predicators: (constant), Prevention/Treatment of AIDS: G, causal factors of AIDS: A, AIDS do not exist, prevention/Treatment of AIDS: B

b. Dependent variables: Changed negative perception about AIDS. 


\section{Discussion}

The bio-data analysis of the age group of the respondent revealed that age 14-25 was significantly higher than their counterparts age 26-50. This was because the group 14-25 constitutes the major school population in Nigeria. This corroborates with the finding of Pennington (2006) who discovered that $60 \%$ of all reported cases of HIVIAIDS are within the age brackets of $15-24$ years and constitute about $50 \%$ of the national population.

The data in table 3 revealed that $23.2 \%$ of the respondents still believe that AIDS does not exist despite all the education and enlightenment programmes of the Federal Government and both National and International NGO's activities and interventions. This was supported by Olaseha and Alao (1993), who opined that all schools had very poor knowledge of AIDS causation, mode of transmission, symptoms, prevention and control of disease. Udonsi (2004) in his research had similar experience. Unprotected sexual intercourse with infected person was strongly supported as accusative factors of HIVIAIDS as revealed by $85.4 \%$ of the sampled respondents. This implies that knowledge of the causes of HIVIAIDS is not a pointer for the students' involvement in risky-sexual behaviours. Kiragu (2001), pointed out that some youths engaged in unsafe sexual-behaviour after being diagnosed positive. With having multiple partners, the respondents opinion was vehemently rejected with $1247(77.9 \%)$ disassociating themselves from such risk-behaviour and practices. However, some of the respondents $22.1 \%$ still persist on having multiple sexual partners.

The result of the analysis with reference to the differences between HIVIAIDS of knowledge of students in the two college of education revealed no significance difference with (df $-15, p>0.5)=2.036$ ). This could be attributed to their involvement in same type of cultural belief. The students are from the same- like environment community and practice almost the same type of religion. Their sources of information are virtually the same and operate the same school curriculum; and rely on peers for information about their sexuality. This was supported by Pennigton (2006) research which reported that sexuality education and services for adolescents remain a silent issue in Nigeria because of religious and cultural belief.

Hypothesis two was subjected also to inferential statistical analysis and the result indicated that there was no significant differences between HIVIAIDS risk behaviour among the students of the two colleges of education as seen in the t-test analysis thus $f(d f=15, p>.05)=1.242)$. One expects that there should be some differences between Ekiadolor College of Education students being urban than the rural setting of Igueben College of Education Students. However the t-test analysis disapproved that assumption. So many factors could influence their sexual behaviour such as the polygamous nature of the Edo's, the setting of the research. Religious belief and practices and economic factors are important factors. Population reports (2002), indicated that in a climate of deprivation young people especially women are particular at risk. When the hypothesis was subjected to multiple regression analysis, the result revealed that HIVIAIDS knowledge of the student does significantly influence students involvement in HIVIAIDS risk-taking behaviour ( $f(d f=5, p>$ $.05)=.941$. A research Rperogi (2002), opined that the 2001 curriculum was introduced for comprehensive sex education for 10-18 years old. It focuses on improving young people's knowledge and attitude towards sexual health thus reducing sexual risk-taking behaviour. Finally Whitehead (1994) discovered that early sex training of teenagers are much more likely to engage in responsible sexual conduct; abstinence, non coital sex or sexual act with condom.

\section{Summary, Conclusion and Recommendation}

The study was conducted to find out the knowledge and risk-taking behaviour on HIVIAIDS of students in two colleges of Education in Edo State South-South Nigeria. A total of 1600 students taken from the college of education formed the study population. The data was collected by administering questionnaire which was validated and test for reliability. The data collected was analyzed using descriptive statistics of frequencies and percentage while inferential statistics of t-test and multiple regression analyses was used to test the hypotheses at 0.05 level of significance. Tables were used to report the findings.

Based on the finding of the study, the following conclusion were reached and drawn:

- Young people need a lot of education to be aware of the risks involved in been HIVIAIDS positive. Despite the 24 years of both national and international recognition given HIVIAIDS young people still have limited opportunities to fully learn and know what the HIVIAIDS could be. Misinformation and misconception is till dominating the lives of our youth in Nigeria.

- Stigmatization and discrimination of HIVIAIDS vulnerable is still common in all spheres of this country, people have not learnt enough about the mode and transmission of the disease.

- The AIDS education in the curriculum of school is not properly taught. There are not enough hands to manage 
the subjects.

- The curriculum should be driven to all sector of the workforce. This should not only be targeted at higher institutions but included in the curriculum of school from primary to higher institutions.

- Since Colleges of Education are avenues for reproduction of teachers, HIVIAIDS education should not only be incorporated into curriculum but should be taught effectively.

- Seminars and workshops should be organized for the teachers, bankers, civil servants, private officers, churches, mosques and market women to enhance knowledge and create awareness.

- International organizations should be given cudos and then sort for more help and funds from them to organize and fund more oriented projects that would benefit the masses. Such fund should be judiciously utilized for the purpose. Rural areas should be visited.

- Finally HIVIAIDS testing centres should be created more in the rural areas and awareness on the importance of creating these centres.

\section{References}

Federal Ministry of Health (2003). National HIVIAIDS and reproductive health survey.

Federal Ministry of Health (2006). Technical Report 2005. National HUV / syphilis sero -prevalence sentinel survey among pregnant women attending antenatal clinics in Nigeria. Abuja.

Gesto, A.M. (2004). Nigeria school and HIVIAIDS: The Team Approach Solution: Nigeria School Health Journal 16(182) 1-9

Kperoji, F.A. (2002). Proposed Sex Education for schools; Who will accept it? This week Trust 4, 36-42

Kiragu, K. (2001). Youth and HIVIAIDS: can we avoid catastrophe? Population Reports Services. Baltimore; 12, 1-14.

Muyiwa, E.D. (1989 November 6). No more a private Affair. This week, 11.

Nkya, W.M. Gillespie, S.H. \& Howlet, W. (1991). Sexually transmitted diseases in prostitutes in Moshi and Arusha Northern Tanzania. International Journal of STD and AIDS, 2.432-5

Olaseha, I. \& Alao, A. (1993). Knowledge, attitude and risky behaviour of adolescent students; Towards AIDS prevention and control in Ibadan city, Oyo State Nigeria. Nigeria school Health Journal 8(1) 110-114.

Pennington, J. (2006). HIV and AIDS in Nigeria: The World Bank Population Reports (2002). Adolescent behaviour increases vulnerability.

Udonsi, C; Kinyanjui, C., Emmanuel, J. \& Abdul, (2004) Understanding the needs and rights of adolescents in relation to HIVIAIDS. A participatory action research process. Action aid, Abuja, Nigeria.

Epidemic update, (2001). UNAIDS, Geneva.

Report, A joint response to AIDS. (1991). UNAIDS, Geneva. Children and HIVIAIDS: (2003 June 26). UNESCO No. 103,

Initiative on HIVIAIDS preventive Education: strategies plan of action. (2003). UNESCO Abuja

U.S. Department of State (2008). Accessed August 25, 2008. This article incorporates text from this source, which is in the public domain

Whitehead, (1994). The failure of sex Education The Atlantic Monthly, 32-35, 55-80. Retrieved March 8, 2005 from http://catholiceducation:org/Articles/sexuality/se0007.html. 
ISSN 2239-978X

ISSN 2240-0524
Journal of Educational and Social Research MCSER Publishing, Rome-Italy
Vol. 4 No. 6 September 2014 